\title{
Multicriteria spatial analysis applied to identifying ecosystem services in mixed-use river catchment areas in south central Chile
}

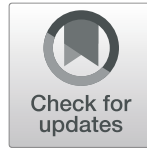

Carlos Esse ${ }^{1,2^{*}}$ D, Rodrigo Santander-Massa ${ }^{3,4}$, Francisco Encina-Montoya ${ }^{5,6}$, Patricio De los Ríos 5,6,

David Fonseca ${ }^{5,6}$ and Pablo Saavedra, ${ }^{1,6}$

\begin{abstract}
Background: The flow of goods and services occurring in catchment areas allows the production of a series of ecosystem services. These have a direct impact on the inhabitants of the territory, who in turn recognise and value ecosystems (social value) as a function of the benefits which they generate. This has a direct impact on public policies that contribute to the development of local economies. The present study therefore sought to identify and recognize the social value of the various ecosystem services provided by a mixed-use catchment area in which different productive activities are concentrated. This study examined the social value of ecosystem services and offers qualitative or quantitative, non-monetary estimates of the relative importance of different benefits for human society derived from the functioning of ecosystems (Laterra et al, Valoración de Servicios Ecosistémicos, Conceptos, herramientas y aplicaciones para el ordenamiento territorial, 2011). The methodology involved the participation of leading actors in the territory, and a panel of experts who defined criteria and weighting which were applied to a multicriteria spatial model. They assigned ordinal scale to the territory representing levels of appreciation based on the various ecosystem services in the ecological, productive, landscape and cultural dimensions. The results showed that the inhabitants of the territory recognise the ecosystem benefit of areas covered by native forest, in particular the species Nothofagus dombeyi (Mirb.) Oerst., in contrast to areas used for farm production. The functioning of the ecosystem is recognised, and particularly its contribution to regulating water flows and to water production and quality.

Results: The study results showed that areas covered with secondary forest of $\mathrm{N}$. dombeyi provide a variety of ecosystem functions which support the creation of ecosystem services to the population, especially in riparian areas throughout the basin where they are important for water production and quality. ES ponderations for provision, regulation and cultural showed that the native forest and riparian units (HEU 1 and HEU 6) as a very important group in relation to the ES because there are recognized by the local society $(P<0.05)$. The leading actors assigned a low social value to other landuses, like mixed use and farmland, because of the high degree of anthropisation of these ecosystems; this viewpoint has generated conflicts in the territory. Neither foresters nor farmers recognise or accept the impacts of their activities on the various ecosystem services provided by the territories where they operate, even though they are leading actors for the development of local economies.

(Continued on next page)
\end{abstract}

\footnotetext{
* Correspondence: carlos.esse@uautonoma.cl

'Unidad de Cambio Climático y Medio Ambiente (UCCMA), Instituto de Estudios del Hábitat (IEH), Facultad de Arquitectura y Construcción, Universidad Autónoma de Chile, Avenida Alemania No, 01090 Temuco, Chile ${ }^{2}$ Centro de Investigación Multidisciplinario de La Araucanía (CIMA), Universidad Autónoma de Chile, Avenida Alemania Nº, 01090 Temuco, Chile Full list of author information is available at the end of the article
} 


\begin{abstract}
(Continued from previous page)
Conclusion: The participation of the leading actors of a territory, represented spatially in a multicriteria analysis model, highlighted the social value of the ecosystems present in a hydrographic catchment area which supports different productive and conservation activities. The model contributed to understanding of the functional processes which generate goods and services present in the physical medium. The study used a hybrid method which included definition of homogeneous environmental units and multicriteria and multivariate statistical analysis. This allowed the information provided by the actors in the territory to be analysed with different spatial scales, levels of perception and elements of territorial planning which contribute to the generation of public policies and the sustainable management and conservation of natural ecosystems.
\end{abstract}

Keywords: Coihue, Water quality, Goods and services, Sub-catchment areas, Riparian areas

\section{Background}

Natural systems provide numerous goods and services to human society, supporting human welfare and economic prosperity (MEA 2005). Among these goods and services are food production, regulation of the climate, water regulation, etc. (de Groot et al. 2002). Broadly speaking, Ecosystem Services (ES) are the conditions and processes through which natural ecosystems help to sustain human life (Daily 1997). Costanza et al. (1997) define them as those benefits which human populations receive directly or indirectly from ecosystem functions, defined as a set of ecological processes in the structure of an ecosystem (de Groot et al. 2002). Therefore the production of an ES will depend on the structure and processes of an ecosystem; any factor which has an impact on the ecosystem will affect its processes as well as the flow of benefits generated by the ecosystem for society (Costanza et al. 1997; Daily 1997; de Groot et al. 2002; Esse et al. 2014).

In Chile, the current conceptual framework defined by the Environment Ministry (MMA) establishes a classification of ES based on Haines-Yong and Potschin (2013) and Haines-Young and Potschin (2018), who divide these services into: 1) support, intermediate and final services provided by the environment, and 2) the goods and benefits of the economic and social system. Thus we may say that ecosystems are the basic functional units of the ecology, in which we can recognise the constant interaction between biotic and abiotic components (Odum 2004). Ecosystem studies concentrate on describing biological phenomena from a systemic perspective. They involve the three variables which allow these ecological units to function, namely energy flows, nutrient cycles and biomass generation (Rees 2018).

Starting from the conceptual framework proposed by the Millennium Ecosystem Assessment (MEA 2005), a more explicit link has been established between how a service is provided and how society benefits from it (ecological and economic integration of ecosystems), relating function and ES with the benefit to society.
MEA (2005) classifies ecosystem goods and services into four categories: (1) Provision: associated with tangible goods or products obtained from ecosystems; (2) Regulation: benefits obtained from the regulation of complex ecosystem processes by which environmental conditions are regulated; (3) Cultural: immaterial benefits obtained from ecosystems; and (4) Support: basic ecological processes to ensure proper ecosystem functioning and the flow of provision, regulation and cultural services. Other classifications exist, such as those proposed by Boyd and Banzhaf (2007), Wallace (2007), Fisher and Turner (2008) and TEEB (2010); they differ in the breadth and complexity of their approaches.

In geographical space, where the processes which generate the various ES occur, the territorial dimension is an integrating element which must be carefully studied (Zasada et al. 2017). Sánchez (2009) stresses the importance of territory, due to the endogenous capacity of actors to establish connections and flows, both material and immaterial; linking those involved who are inserted in different and sometimes distant territorial scales. Thus the spatial representation of ES in the territory allows the public resources and policies for safeguarding these services to be properly directed (Esse et al. 2014). Citizen participation is a key aspect; it must be considered when ES are being identified (Verburg et al. 2016), since the inclusion of local actors allows respect for their identity and other aspects which are unlikely to be recognised. Little attention is usually paid to this aspect in policy planning and drafting (Braat and de Groot 2012), where the tendency all over the world is towards the 'upscaling' model (Larsen et al. 2012), using results as the basis for larger-scale policies, for example at national level. In citizen participation processes, the leading actors in the territory possess more information on the flow of goods and services produced in the environment where they carry on their own productive activities (Costanza and Shuang 2014); their perception does not always coincide with that of specialists and researchers, who seek to understand the flow of goods and services by establishing 
a conceptual model (Hermelingmeier and Nicholas 2017) which excludes the knowledge of those who live in the territory. This needs to be corrected to achieve greater accuracy and knowledge about ecosystem production derived from the physical medium (Peterson et al. 2018), as occurs when the functioning of native forest is compared with that of forestry plantations.

In the mid-nineteenth century, the forest landscape of Chile underwent a major transformation due to the felling and burning of vast expanses of native forest to clear land for arable and livestock farming (Donoso and Otero 2005; Otero 2006). A hundred years later, the industrial forestry sector was promoted by the passing of the Forest Law and Decree Law No. 701, the object of which was to regulate the felling of native forest and provide incentives for the recovery of degraded soils by installing plantations of fast-growing exotic species (Otero 2006). As a result, there is now growing discussion in south central Chile about the forestry industry and the replacement of large expanses of native forest to promote farming production (Miranda et al. 2015), and the possible impact that this has on ecosystem functioning in river catchment areas, and especially on the services associated with water production and quality (Oyarzún et al. 1997; Soto 2002; Naiman et al. 2005; Richardson et al. 2007; Lara et al. 2009; Little et al. 2009; De los Ríos Escalante et al. 2017). This situation has led the inhabitants of these basins to assert their agreement with criteria for the conservation and preservation of native forest; they are supported by Law 20.283, which regulates the recovery of native forest and promotion of the forestry industry, in order to avoid restrictions on the production of forest goods and services and damage to the potential development of local economies.

In view of the above, our purpose was to assess the social value assigned by important actors in the territory to the production of goods and services by secondary $N$. dombeyi forests in a catchment area with multiple land-use. We expected to find significant recognition by important actors of the production of goods and services by $N$. dombeyi forests as compared to other land-uses. The object of the present study was therefore to identify and analyse the social value of ES, considering different levels of perception in a catchment area which supports a variety of forestry and farming activities. We hope that the results will help in the drafting of public policies to regulate activities in the territory, contributing an easily-applied methodology for including the perceptions of the territory's inhabitants and leading actors.

\section{Materials and methods}

\section{Study area}

The study catchment area is part of the upper Quepe River basin, located in the precordillera zone of south central Chile $\left(38^{\circ} 40^{\prime} \mathrm{S}-71^{\circ} 45^{\prime} \mathrm{W}\right)$. The annual precipitation in the area varies between 2300 and $2400 \mathrm{~mm}$ (Di Castri and Hajek 1976; Luebert and Pliscoff 2006). The climate is wet warm-temperate with mediterranean influence lower down, and wet cold-temperate with mediterranean influence on the high ground; temperatures are relatively low throughout the year (Luebert and Pliscoff 2006). The soil is deep, well-drained silt-loam with nil to slight erosion over the whole area (CIREN 2002). The basin presents sectors under various types of land-use (Fig. 1) including: (1) commercial forest consisting mainly of secondary forests of $N$. dombeyi at the top of the basin; (2) mixed use in the middle sector, consisting of forestry plantations, native forest and pasture; and (3) farm use in the lower sector, in areas used almost exclusively for agricultural production.

\section{Definition of homogeneous environmental units (HEUs)}

This methodology is an adaptation of the method proposed by Esse et al. (2014). It was applied in the study area to identify ES provided by the catchment area in general, and to validate the application of the method. The HEUs in which land-uses occur over continuous areas were identified, considering them as territorial units with uniform behaviour in situations of various possibilities dictated by the ecological, cultural, productive and landscape dimensions of the territory (Gómez-Orea 1999). The HEUs were defined through classification by a panel of experts, which was then corrected and validated by leading actors in the territory. This allowed the social perception of the inhabitants to be incorporated, generating spaces for participation and giving the territory an identity. The second stage, once the HEUs had been defined, was the identification of ecosystem services. We used the list of services proposed by the MMA, which is based on Haines-Yong and Potschin (2013) and recognises the different services associated with provision, regulation and culture, the groups which explain the ecosystem functioning of the territory (Table 1). The present study, unlike Esse et al. (2014), included riparian areas as an important HEU; it also included multivariate analysis, a larger number of participants in the workshops, and analysis of the specific ES for different land-uses present in the catchment area, especially areas covered by $N$. dombeyi secondary forest.

The leading actors for the territory were selected by analysis of social networks following Delgado-Aguilar et al. (2017). The technique used was participative mapping, in the following stages: (a) formation of random groups of three or four people; (b) assignation of a map of the study area to each group; (c) giving a list of coded ES to each member of the groups; (d) receiving the reply form in order to draw up a table of frequencies with five classes, which was then analysed by multivalent statistical 


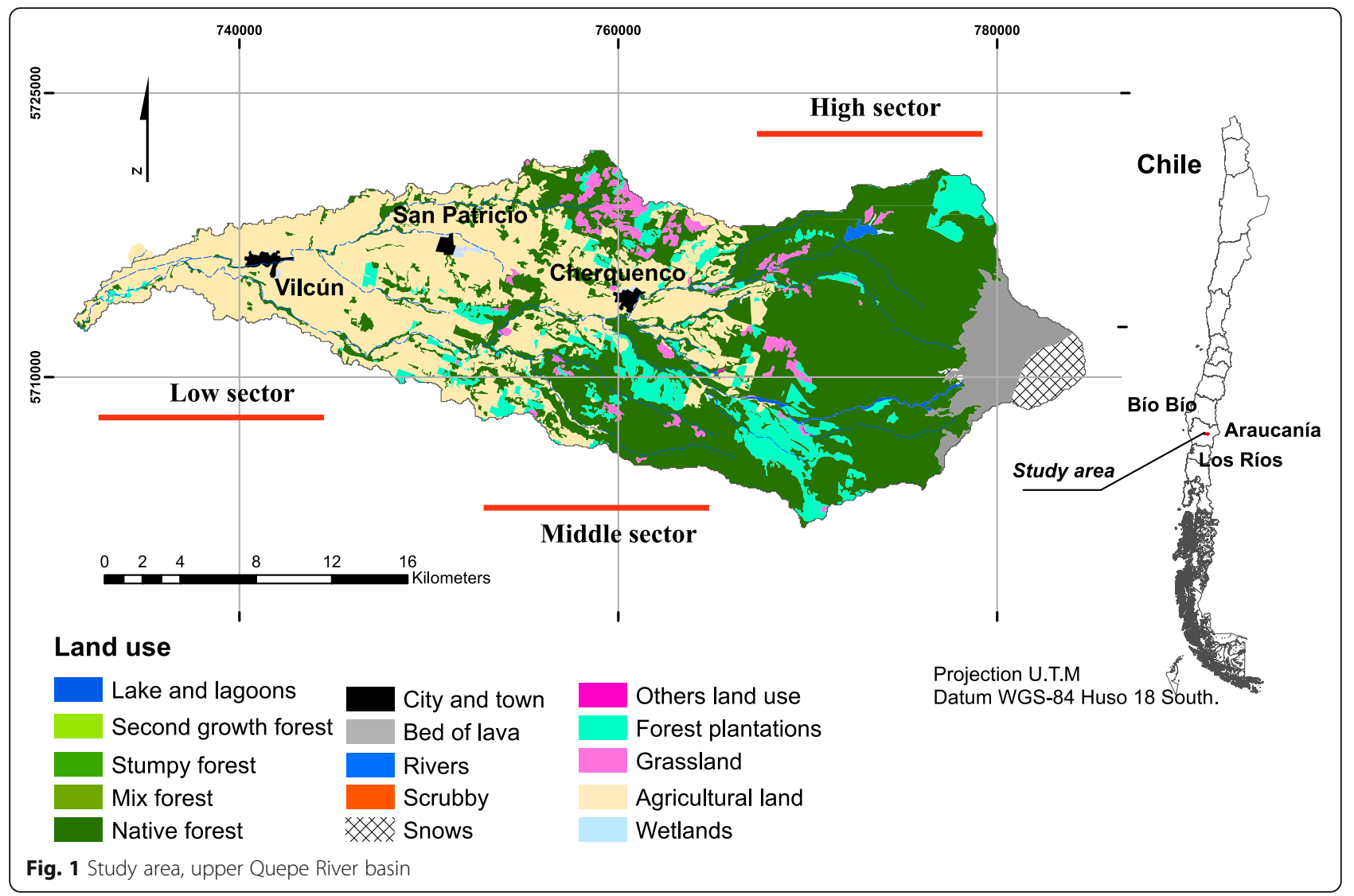

methods. The actors assigned ES to different HEUs individually to avoid bias in the replies.

\section{Construction of the multicriteria spatial model (MSM)}

The frequency table was subjected to multivariate principal component analysis (Quinn and Keough 2002). This allowed the most important variables to be selected and the number of variables reduced. Selection of the variables was based on the 70 percentile applied to the contributions of the weighted observations on the factorial axes selected. The object of this was to provide an objective weighting rule based on the recorded frequency, generating a spatial expression of the perception of the leading actors for each of the ecosystem service groups. The model used was a weighted linear equation for each group of services (1).

$$
M S M-G_{S E}=\sum_{i=1}^{n} S E_{i} \times P_{i}
$$

where $M S M-G_{S E}$ corresponds to the social value or level of importance of the ES according to the assessment of the important actors in the territory; $S E_{i}$ is the ES selected from the 70 percentile; and $P_{i}$ is the value of the contributions of the weighted observations on the factorial axes (2).

$$
P_{i}=\sum_{i=1}^{n}\left(f_{i} \times 100 / f_{i}\right)
$$

where $f_{i}$ is the frequency value of the ES on the 70 percentile validated by the panel of experts.

Non-metric multidimensional scaling (nMDS) was used to distinguish similar groups of HEUs. In addition, a hierarchical agglomerative clustering analysis was performed applying Single linkage and using Euclidean distance. To identify the groupings objectively, the SIMPROF test was carried out (Clarke et al. 2014). It was established whether the ecosystem services in a study unit, as a whole, differ between sites (ANOSIM). The services which contributed to the differences in HEU composition between study units were analysed by similarity percentage analysis (SIMPER).

ArcGIS v10.6 software was used for the spatial analysis, and the cartographical bases in vector and raster format were taken from Catastro de los Recursos Vegetacionales de Chile [Register of the Native Vegetation Resources of Chile] (CONAF 2013). The statistical analyses were done using the $\mathrm{R}$ software in the factoextra (Kassambara and Mundt 2017) and ggplot2 (Wickham 2009) packages. 
Table 1 Groups of ecosystem services defined by the Environment Ministry (MMA), Chile

\begin{tabular}{|c|c|}
\hline Code & Provision Ecosystem Services \\
\hline APR & Rural Drinking Water \\
\hline APU & Urban Drinking Water \\
\hline RIE & Irrigation \\
\hline PRI & Industrial processes \\
\hline PDV & Sport fishing \\
\hline PAR & Artisanal fishing \\
\hline PIN & Industrial fishing \\
\hline ACUI & Aquaculture \\
\hline $\mathrm{HCU}$ & Hydrocultures \\
\hline JAN & Energy (hydroelectric, biomass and geothermal - in process) \\
\hline ARD & Sand and gravel \\
\hline PLM & Medicinal plants \\
\hline TRA & Transport \\
\hline APS & Pasture, livestock (watering points, summer grazing, dairies) \\
\hline MAD & Wood \\
\hline ALG & Algae (micro and macro) \\
\hline AMl & Mineral water (in process) \\
\hline FLO & Flora (except algae) \\
\hline FAU & Fauna \\
\hline ABA & Hot mineral water and mud \\
\hline PSE & Seed production \\
\hline AMA & Management areas (natural banks) \\
\hline HAT & Hatcheries (in process) \\
\hline ART & Handicrafts and weaving \\
\hline PFNM & Non wood forest products \\
\hline PURI & Slurry and dung \\
\hline Code & Regulation Ecosystem Services \\
\hline DDC & Elimination of dilution with non-organic pollutants \\
\hline $\mathrm{RCO}$ & Regulation of organic pollution \\
\hline RCT & Regulation of thermal pollution \\
\hline $\mathrm{RCL}$ & Climate regulation (micro and macro) \\
\hline RSE & Sediment retention \\
\hline RIN & Flood regulation \\
\hline RGE & Erosion regulation \\
\hline RPS & Regulation of primary /secondary productivity \\
\hline $\mathrm{RCN}$ & Nutrient cycle regulation \\
\hline CES & Surface run-off control \\
\hline $\mathrm{CCO}$ & CO2 sequestration \\
\hline ANH & Natural attenuation - hydrological/hydrogeological variability \\
\hline DCC & Degradation of pollutant loads \\
\hline CRE & Resilience \\
\hline ATS & Tsunami attenuation. \\
\hline Code & Cultural Ecosystem Services \\
\hline
\end{tabular}

Table 1 Groups of ecosystem services defined by the Environment Ministry (MMA), Chile (Continued)

\begin{tabular}{ll}
\hline CTT & Thermal centres \\
EXC & Excursions (without accomodation) (EXC) \\
BAL & Bathing resorts (resolution by DIRECTEMAR) \\
CRE & Recreation centres (CR) \\
TUR & Tourism (with accomodation) (TUR) \\
BEE & Natural beauty (BES) \\
VET & Ethnic value (VET) \\
DNA & Watersports \\
CEI & Science and research (CIN) \\
EDU & Education (EDU) \\
SCE & Ceremonial sites \\
CPE & Fishing quays \\
NAV & Navigation (with or without motor) \\
VCE & Cultural value of particular species \\
MNC & Non-conventional medicine (MECON) \\
PFN & PFNM products (clothes dyes, handicrafts, bee-keeping) \\
SIG & Quiet enjoyment (legal term) \\
\hline
\end{tabular}

XLSTAT version 4.03, Statgraphics plus 5.1 and PRIMER version 6 programmes were also used.

\section{Results}

Homogeneous environmental units (HEUs)

A total of seven organisations, consisting of 42 adults, were identified as leading actors in the territory (Table 2). This group agreed with the HEUs proposed by the panel of experts. The results highlight the high social value attributed to the presence of native forest in the territory, related with water production and regulation of water flows in the basin.

A total of six HEUs were identified in the territory, based on relative importance and area covered (Table 3). The largest HEUs were of native forest (45.43\%), followed by farmland (32.07\%) and forestry plantations of exotic species. The important actors in the territory lay stress on native forest management and farming,

Table 2 Key actors in the territory for the definition of HEUs and identification of Ecosystem Services (ES)

\begin{tabular}{llll}
\hline Organisation & $N^{\circ}$ & District & Location \\
\hline NGOs & 6 & Temuco & Temuco \\
University & 6 & Temuco & Temuco \\
Municipality & 4 & Vilcún & Vilcún \\
Neighbourhood association & 8 & Vilcún & Vilcún-Cherquenco \\
Environmental committee & 4 & Vilcún & Cherquenco \\
Retailers' association & 8 & Vilcún & Vilcún-San Patricio \\
CONAF & 6 & Temuco & Temuco-Los Paraguas \\
\hline
\end{tabular}


Table 3 Current land-use for the basin and sub-basins presenting different land-uses as a function of their homogeneous environmental unit

\begin{tabular}{llll}
\hline HEU & Current use & Area of basin (ha) & Percentage (\%) \\
\hline 0 & Unclassified & 3931.86 & 7.26 \\
1 & Native forest & $24,598.91$ & 45.43 \\
2 & Lakes-ponds & 95.97 & 0.18 \\
3 & Plantations & 4639.31 & 8.57 \\
4 & Pasture & 1416.00 & 2.62 \\
5 & Farmland & $17,366.87$ & 32.07 \\
6 & Riparian areas & 2096.70 & 3.87 \\
Total Area & & $54,145.62$ & 100 \\
\hline
\end{tabular}

stating that these two activities support an important part of the local economy, which relies heavily on construction timber, firewood, tourism, exploitation of Non Wood Forest Products (NWFP) and cereal farming.

The areas covered by native forest are dominated by $N$. dombeyi (Coihue) which forms part of the Roble-Raulí-Coihue and Coihue-Raulí-Tepa forest types (Fig. 1). The upper basin contains a large area of $N$. dombeyi secondary forest, as do the riparian areas where this species forms long river galleries. This species covers a large proportion of the whole catchment area
(50\%). The middle sector of the basin presents mixed land-use, with high presence of native forest and a variety of species belonging to the Roble-Raulí-Coihue forest type. The ground is covered with semi-dense and open scrub, clearly showing different degrees of degradation produced by the anthropic pressures of the farming and forestry activities carried on here (Fig. 1). The landscape also contains pasture and intensive farming land belonging to the big producers of this zone. The lower part of the basin is mainly used for arable farming with large areas of highly technified crop production (Fig. 1). The majority of the land is owned by a small number of families. The effects of the high pressure of this land-use are apparent. It is remarkable that in this sector the riparian areas present little native vegetation, since these areas have been taken in for crops (Table 3).

\section{Selection of ecosystem services}

The principal component analysis showed, for each ES, that components 1 and 2 explain over $70 \%$ of total variability. A total of eight production services were selected (Table 4); they are directly related with the presence of native forest and water bodies. Four regulation services were selected, of which $\mathrm{CO}_{2}$ sequestration and erosion control are cited as the most important, especially in areas covered by forest and pasture. Five cultural services were identified in the analysis, the most notable being science

Table 4 Provision, regulation and cultural ecosystem services selected

\begin{tabular}{|c|c|c|c|}
\hline Model & Variables & $\%$ & Multicriteria Spatial Model \\
\hline \multirow[t]{8}{*}{ Production } & (1) Rural Drinking Water (APR) & 11 & \multirow{8}{*}{$\begin{array}{l}\text { MSM-G } \text { prod. }=\mathrm{APR}^{*} 0.11+\mathrm{APU}^{*} 0.11+\mathrm{PAR}^{*} 0.11+\mathrm{PIN}^{*} 0.12+\mathrm{PAS}^{*} 0.13+ \\
\mathrm{FLO}^{*} 0.13+\mathrm{FAU}^{*} 0.15+\mathrm{PSE}^{*} 0.16\end{array}$} \\
\hline & (2) Urban Drinking Water (APU) & 11 & \\
\hline & (3) Artisanal fishing (PAR) & 11 & \\
\hline & (4) Industrial fishing (PIN) & 12 & \\
\hline & $\begin{array}{l}\text { (5) Grazing, livestock (watering points, summer grazing, } \\
\text { dairies) (PAS) }\end{array}$ & 13 & \\
\hline & (6) Flora (except algae) (FLO) & 13 & \\
\hline & (7) Fauna (FAU) & 15 & \\
\hline & (8) Seed Production (PSE) & 16 & \\
\hline \multirow[t]{4}{*}{ Regulation } & (1) Elimination of dilution with non-organic pollutants (DDC) & 22 & \multirow[t]{4}{*}{$M S M-G_{\text {regul. }}=\mathrm{DDC}^{*} 0.22+\mathrm{RGE}^{*} 0.23+\mathrm{CCO}^{*} 0.27+\mathrm{CES}^{*} 0.28$} \\
\hline & $\begin{array}{l}\text { (2) Erosion Regulation Erosion (RGE)(2) Erosion Regulation } \\
\text { Erosion (RGE) }\end{array}$ & 23 & \\
\hline & (3) $\mathrm{CO}_{2}$ sequestration $(\mathrm{CCO})$ & 27 & \\
\hline & (4) Surface run-off control (CES) & 28 & \\
\hline \multirow[t]{5}{*}{ Cultural } & (1) Thermal centres (CCT) & 21 & \multirow{5}{*}{$M S M-G_{\text {cul. }}=C C T^{*} 0.21+\mathrm{TUR}^{*} 0.18+\mathrm{BEE}^{*} 0.18+\mathrm{CPE}^{*} 0.21+\mathrm{CE} \mathrm{I}^{*} 0.22$} \\
\hline & (2) Tourism (TUR) & 18 & \\
\hline & (3) Natural beauty (BEE) & 18 & \\
\hline & (4) Fishing (CPE) & 21 & \\
\hline & (5) Science and research (CEI) & 22 & \\
\hline
\end{tabular}


and research, tourism, and activities associated with sport fishing. In the provision group, the effect of the factorial axes gave weighting to the ES of flora, fauna and seed production, which received the highest scores. In the regulation group, the highest scores were given to $\mathrm{CO}_{2}$ sequestration and surface run-off control. In the cultural ES group, the highest weightings were given to science and research, and fishing (Table 4).

The weightings and factorial analysis for provision ES showed on the first plane (Fig. 2a) that the variable which correlated with HEUs consisting of arable farmland, pasture and plantations was grazing; in the case of the native forest HEU, there was a high correlation with flora, medicinal plants and irrigation; the riparian HEU showed a high correlation with urban and rural drinking water. In the case of the regulation ES (Fig. 2b), it was found that the pasture and arable land HEUs were correlated with control of run-off and a high resilience in the ecosystem; the plantations HEU was correlated with control of erosion and flood-risk; the native forest, riparian areas, and lakes and ponds HEUs showed a high correlation with contaminant elimination, carbon sequestration and climate regulation. Finally, for the cultural ES (Fig. 2c), the results showed that the plantations HEUs are correlated with education, while pasture and arable land HEUs in Quadrant I and native forest in Quadrant IV are correlated with non wood forest products and science and research.

\section{Non-metric multidimensional scaling}

The results of the SIMPROF and ANOSIM analysis for the provision ES group (Fig. 3a) showed that HEU 1 and HEU 6 differ significantly from HEU 3, 4 and 5 and from HEU $2(P<0.05)$. The services which account for the similarity of $60 \%$ are medicinal plants, flora, rural drinking water, aquaculture, sport fishing, artisanal fishing and irrigation. For the regulation ES group (Fig. 3b), HEU 1, HEU 2 and HEU 6 differ significantly from HEU
4 and 5 and HEU $3(P<0.05)$. The services that contribute the most to the group formed by HEU 1, 2 and 6 are nutrient cycle regulation, regulation of thermal pollution, climate regulation, flood regulation, $\mathrm{CO}_{2}$ sequestration and degradation of pollutant loads. For the cultural ES group (Fig. 3c), HEU 1, HEU 2 and HEU 6 differ significantly from HEU 4 and 5 and HEU $3(P<0.05)$. The services that contribute the most to the group formed by HEU 1, 2 and 6 were thermal centres, navigation, bathing resorts, quiet enjoyment and water sports. In general, the results of the non-parametric analysis showed that soil covered by secondary forest of $N$. dombeyi support a group of important ecosystem functions, recognised by the important actors of the territory.

\section{Spatial model for ecosystem services}

The weightings assigned $\left(P_{i}\right)$ to each ES generated the $M S M-G_{S E}$ for each group (Table 4). The results of each $M S M-G_{S E}$ showed that for provision services especially (Fig. 4a), the greatest value to the territory in the basin is derived from the presence of native forest, coinciding with almost $50.0 \%$ of the basin's total area. Secondly, a high value for the territory was assigned to riparian areas, and a lesser value to areas containing pasture and lakes and ponds, which together account for only $2.7 \%$ of the area. In the case of regulation services (Fig. 4b), the greatest value to the territory was assigned to areas covered by native forest. Finally, under cultural services (Fig. 4c), the greatest value to the territory was assigned to areas covered with native forest, riparian areas, and lakes and ponds, which coincided with the appreciation for provision services.

\section{Discussion}

This study shows that catchment areas are complex systems; they support different ecosystem processes which are usually particular, individual and characteristic, making comparison between them difficult (Esse et al. 2014). These

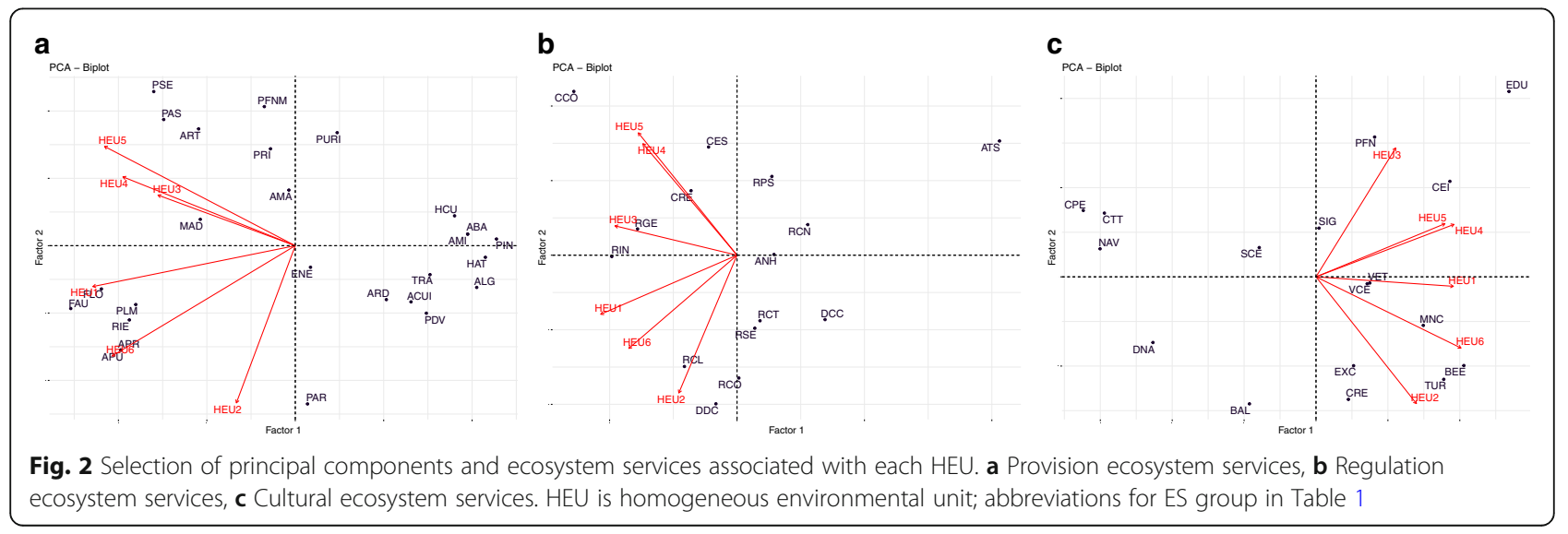




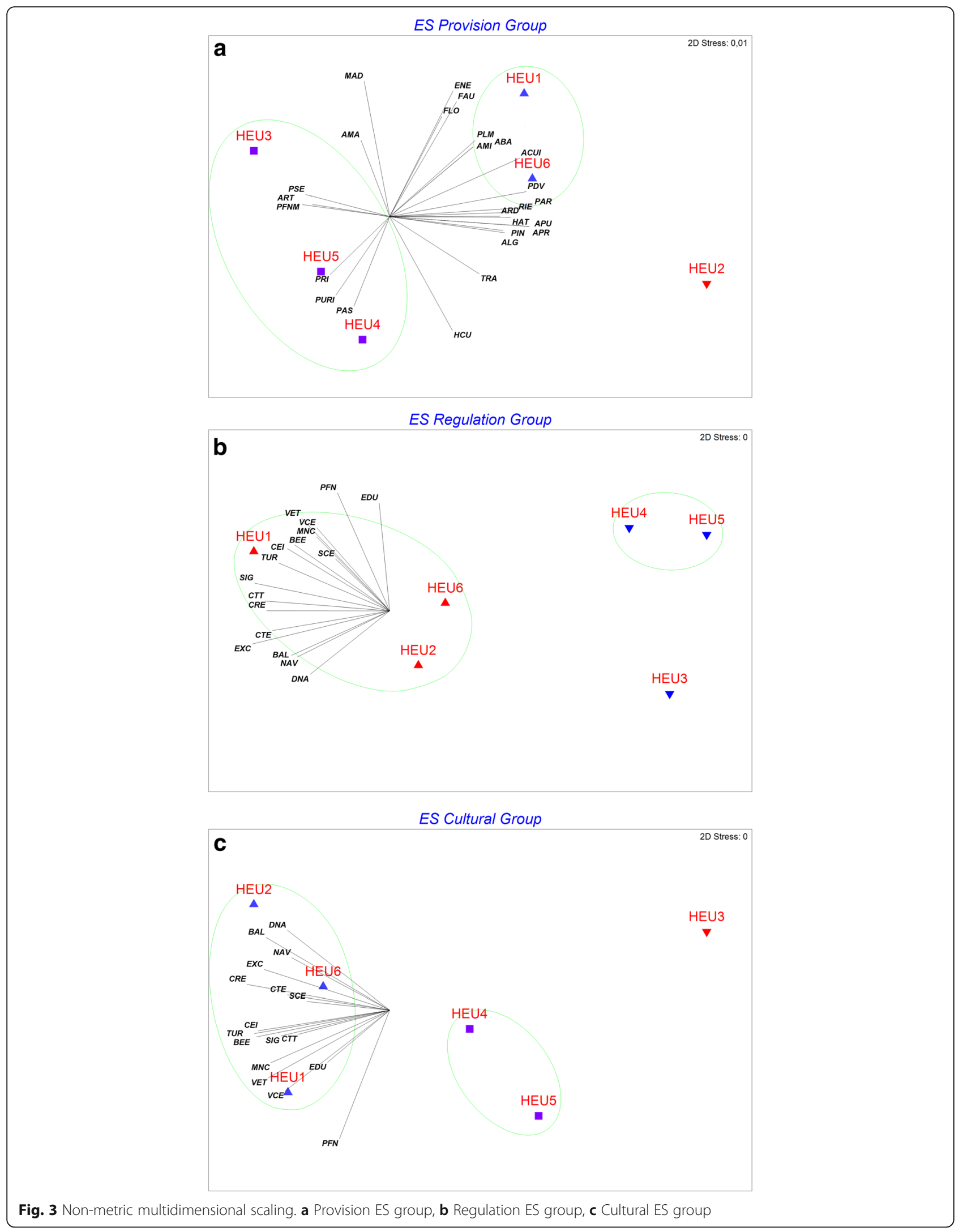




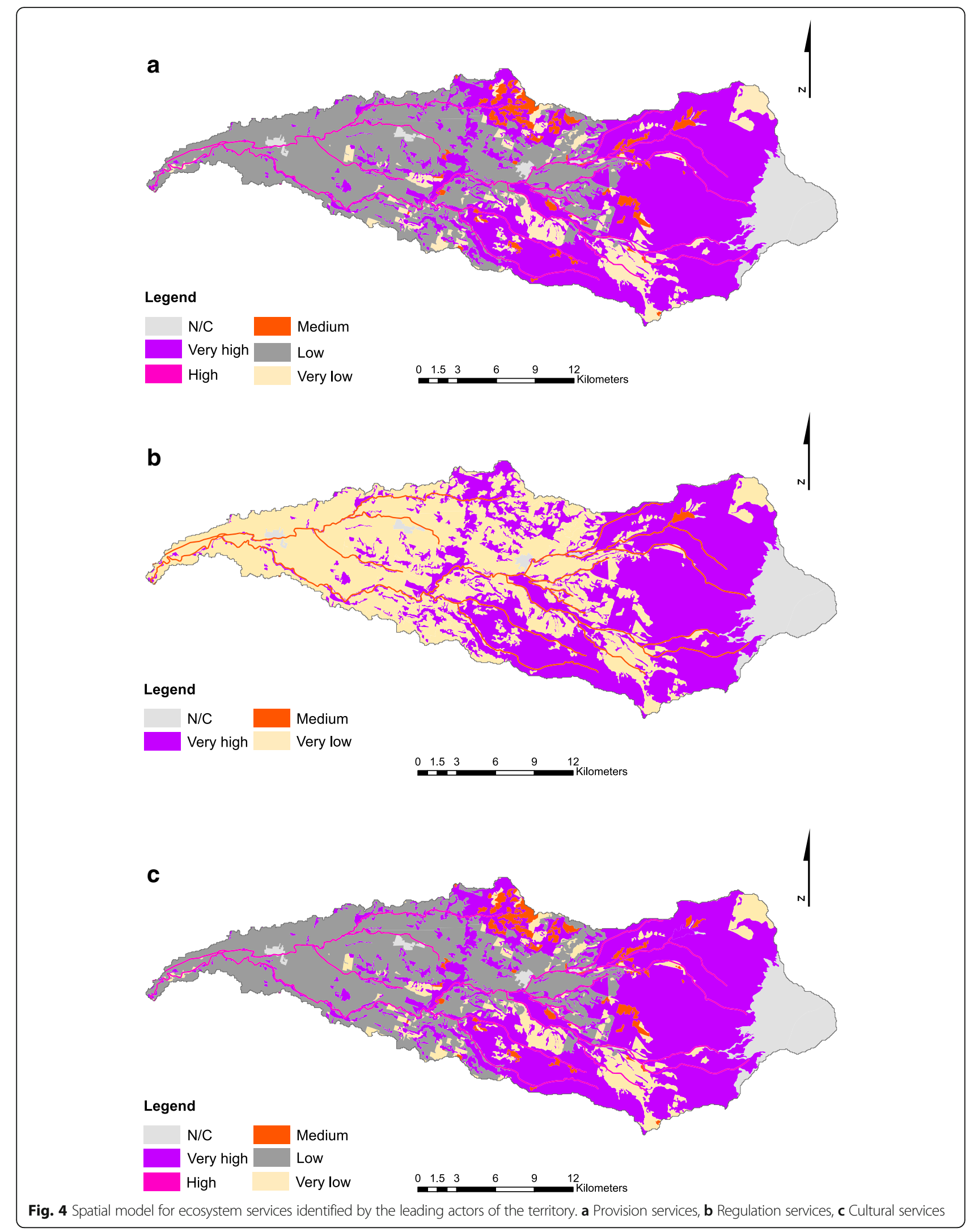


territorial units present different ecosystems throughout their length and breadth, incorporating boundaries which are not merely political or administrative borders, as noted by Rodríguez (2006), Vuscoviuch and Tavares (2011) and Gómez-Orea and Gómez (2014). Proper study requires tools for quantifying and mapping the various components, in order to dimension the flows of goods and services occurring in the basin (Laterra et al. 2011; Esse et al. 2014). The technologies derived from geographical information systems (GIS) and remote detection offer high quality detail and remote observation of the various ecosystems which make up a territory. The results of this study show a methodology that incorporates easy-access technological tools and allows precise information to be obtained on environmental components, similar to Keller et al. (2015); Basco-Carrera et al. (2017); Diaz-Balteiro et al. (2018). The identification of benefits is assisted by the inclusion of leading actors, whose perceptions contribute information on the effects of resource handling and management, and how these relate to conservation plans in the framework of co-management of river catchment areas. Multicriteria analysis methods are a way of discovering the perceptions of the territory's inhabitants while minimising the bias in appreciation. Other researchers have obtained good results using these techniques (Keller et al. 2015; Uhde et al. 2015; Diaz-Balteiro et al. 2018), however the present study proposes a hybrid model which allows spatialisation of the perception of the important actors with respect to ES production, facilitating decision-making for territorial planning and the formulation of public policies. A view of the consequences for land-use of such decisions, incorporating the complexity of the natural environment and its variations in time and space, is indicated by Bateman et al. (2013) as an advantage for decision-making in government policies, demonstrating the advantages of the method applied in this study. Nevertheless, the method presents certain deficiencies such as the scale of the analysis, dependence on territorial cartographic bases and the representativeness of the important actors from the territory who participated in the workshops; all these aspects may affect the quality and accuracy of the model; however, they can be improved as a function of the proposed objects.

The results show that the historical use of the basin has encouraged the growth of arable farming and stock-raising; in fact only $8.6 \%$ of the total area consists of plantations of exotic species, while arable farming and stock-raising occupy $34.7 \%$. Both these activities have been responsible for the substitution of native forest, according to Díaz (2006). This may lead to greater contamination of water bodies, species loss, habitat reduction etc. (Habib et al. 2016; Dassou et al. 2017; De los Ríos Escalante et al. 2017), as well as contributing to the impact on the world $\mathrm{CO}_{2}$ balance by increasing the accumulation of greenhouse gases (GHG) and thus promoting climate change. This is suggested by the leading actors of the area, who recognise the negative effects of these two activities on the ecosystem, especially on $N$. dombeyi forest and the water production and quality services associated with this species. Consequently the leading actors attribute greater social value to areas covered with $N$. dombeyi forest, making it clear that the forestry industry (monocultures) is a business which benefits very few people and does not contribute significantly to the local economy. At the same time, farming bears the greatest responsibility for the disappearance of native forest in the basin, and for generating water pollution and a reduction in soil productivity.

The transformation of large areas from native forest to land-uses like farming and forestry plantations modifies the water flow and supply significantly; this may affect economic activities, as remarked by Habib et al. (2016). Oyarzún et al. (2005) indicate that economic activities related with the production and consumption of market goods like drinking water may be severely affected. The result may be that changes in the production of market goods are passed on to society through the pricing system, affecting people's welfare. The results showed that although they contain sectors of severely degraded native forest, riparian areas possess a high value, since they have a recognised function in water provision, the regulation of bio-geochemical processes and cultural aspects, particularly natural beauty and tourism. These areas are fundamental in the territorial unit, and must be properly managed by policies to encourage and incentivise their conservation, allowing a balance between use and the production of goods and services. One object of a management proposal (Fig. 5) should be the restoration or bio-remediation of such areas.

Most of the provision services identified refer to tangible goods, including water, wood, NWFP, fibres, etc. Turning to regulation services, the results show that these are closely related to air and water quality regulation, as they help to maintain bio-geochemical cycles. They are also directly associated with the presence of native forest, and they are recognised and valued as vital services for human welfare, in agreement with MEA (2005), Lara et al. (2009) and Little et al. (2009). For cultural services, native forest is the most valuable unit in the territory, since local actors associate its presence with natural beauty, the culture and world-view of the Mapuche people, tourism, education and research; these results agree with Esse et al. (2014). Cultural services offer benefits which depend on the collective perception of society, a fact which reveals the social importance attributed to the spiritual, recreational and educational benefits provided by ecosystems. Thus, the methodology applied, based on MSM, represented efficiently the value of the territory, since it was able to express the perception 


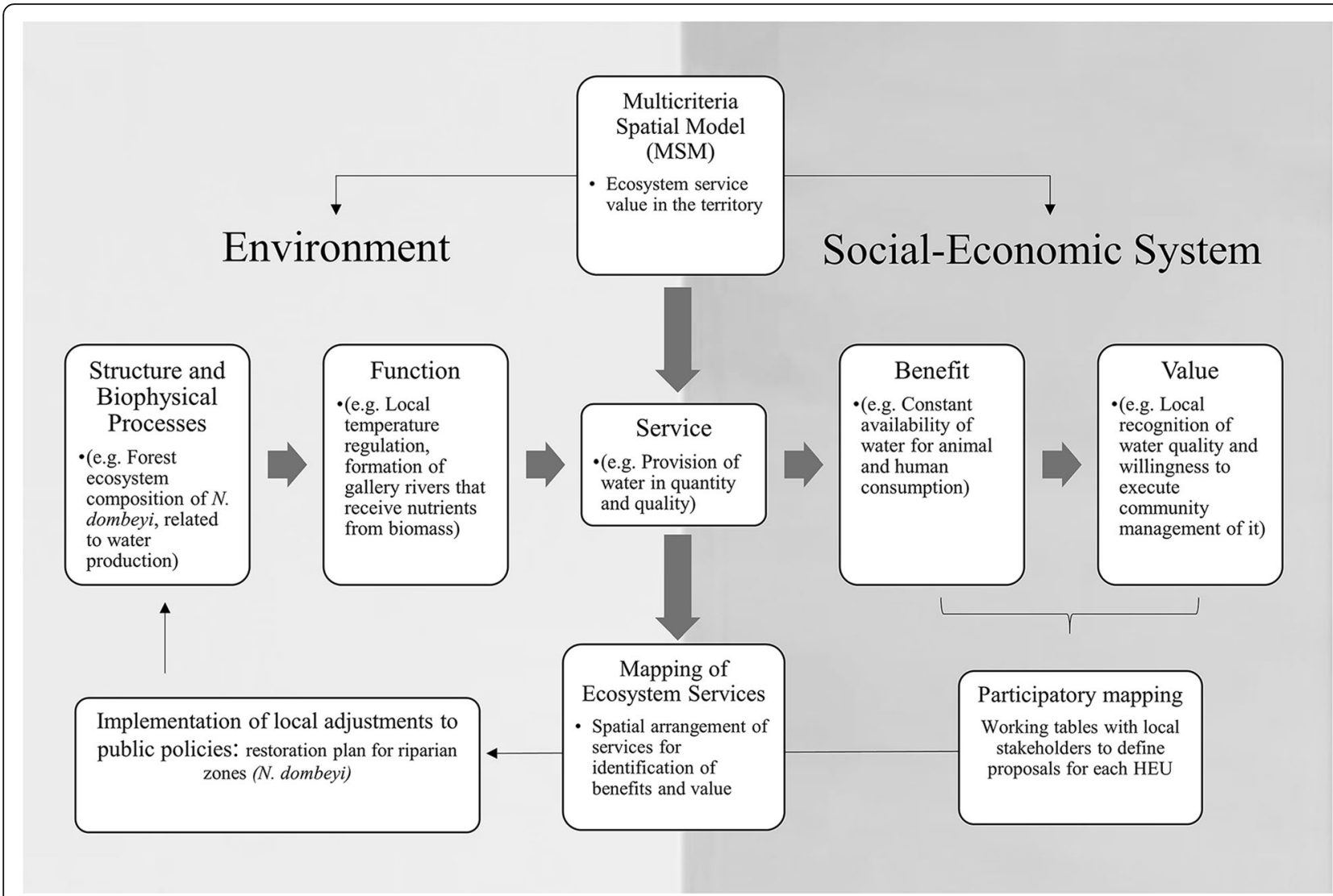

Fig. 5 Management proposal for riparian areas based on the ecosystem functioning of the socio-ecosystem, adapted from Haines-Yong and Potschin (2013)

of the inhabitants of the study area in the spatial plane. This allows options to be created for socio-ecological management through local decision-making, which can be applied on a regional scale as detailed by Larsen et al. (2012). This scaling can be applied in Chile through the authority of the municipal governments to pass mandatory general standards applicable to the local situation, adapted from laws passed at national level (Santander-Massa 2014).

Forestry activity and the replacement of large areas of native forest have altered the ecosystem functioning of the study catchment area, leading to a critical appreciation of such activities among leading actors in the basin. Earlier studies, such as Lara et al. (2003), Echeverría et al. (2006), Lara et al. (2009), Miranda et al. (2015), indicate that the landscape of south central Chile has undergone a series of transformations in recent decades; drastic changes and intense pressure on land-use have resulted in incompatibility between different goods and services. The factors responsible for these changes have been activities like clearing land for agriculture, use of fire, deforestation and degradation of natural forests in areas of high biodiversity (Habib et al. 2016), and wood production in fast-growing plantations relying on irrigation. This reflects the historical reality of the study basin.

The results of the present study recognise the social value of a local viewpoint. This is of great importance for the country's economic development, since it highlights the fact that the conflict between forestry producers and farmers is basically economic, and that their respective positions do not recognise the impacts that they have caused on the ES provided by the territories where they carry on their activities. Thus the participation of the leading actors of the territory is fundamental for generating public policies whose final object is to safeguard the ecosystem functioning of such important areas as river catchments.

\section{Conclusions}

A number of very varied land-uses may be identified in a river catchment area. For this reason, an ecological approach based on ecosystem functioning will give unique, individual results which are unlikely to be comparable with those of other similar geographical units. Correct identification and value attribution of ES will contribute to correct description of the flow of the goods and services affecting the territory. 
The important actors of the territory recognise the importance of native forests, and that they are fundamental for the maintenance of ES related with water production and flow regulation. This is particularly so in the case of $N$. dombeyi forests, which grow in damp conditions associated with watercourses, covering riparian areas. $N$. dombeyi therefore has great potential for use in plans for the restoration of riparian areas.

The methodology used in this study, based on multicriteria spatial analysis, enabled us to represent the territory at landscape scale and to recognise the social value of the different ES of the natural ecosystems and anthropic production systems of which it is composed.

The participation of the leading actors of the territory is fundamental for achieving a proper valuation scale for the different ES; they contribute a broad perspective on territorial management which goes beyond the particular interests of productive sectors such as farming and forestry. Their participation must be reflected in the definition of public policies for the sustainable management and conservation of natural ecosystems.

\section{Acknowledgements}

The authors are grateful for financing from the Comisión Nacional de Investigación Científica y Tecnológica (CONICYT), Chile, through FONDECYT Iniciación Project N¹1160650 (Grant no. 11160650). R. Santander-Massa acknowledges the financing of the second author's postgraduate studies by Fondo de Formación de Capital Humano N²1150903. C. Esse thanks the Research Department of Universidad Autónoma de Chile.

\section{Funding}

This study was financed through FONDECYT Iniciación Project N 11160650 (Grant).

\section{Availability of data and materials}

All the cartographical data used in this study can be found in the territorial information system of the Chilean National Forest Corporation (CONAF), http://sit.conaf.cl and in the Chilean bank of geospatial data, http://www.ide. cl. Own databases were also used. The software programmes used were ArcGis v10.6, licensed by ESRI, and R-project, free software https://www.r-project.org/ with the facto-extra https://cran.r-project.org/package=factoextra and ggplot https://ggplot2.tidyverse.org/ packages. The XLSTAT version 4.03, Statgraphics plus 5.1 and PRIMER version 6 statistical programmes were used.

\section{Authors' contributions}

$\mathrm{CE}, \mathrm{RS}, \mathrm{PR}$, FE were responsible for collecting and analysing the data. The databases were prepared by CE, PS, DF and RS. The manuscript was prepared by CE and RS with contributions by PR and FE. PS reviewed the manuscript and applied the final format, which was agreed by all the authors.

\section{Authors' information}

All the authors are academics involved in environmental management and research. CE is doctor in forest sciences. RS is master in rural development. FE is doctor in environmental sciences, PR is doctor in system sciences and ecology. DF is doctor in agricultural engineering and PS has a degree in natural resource sciences.

\section{Ethics approval and consent to participate}

Not applicable.

\section{Consent for publication}

Not applicable.

\section{Competing interests}

The authors declare that they have no competing interests.

\section{Author details}

${ }^{1}$ Unidad de Cambio Climático y Medio Ambiente (UCCMA), Instituto de Estudios del Hábitat (IEH), Facultad de Arquitectura y Construcción, Universidad Autónoma de Chile, Avenida Alemania Nº 01090 Temuco, Chile. ${ }^{2}$ Centro de Investigación Multidisciplinario de La Araucanía (CIMA), Universidad Autónoma de Chile, Avenida Alemania Nº 01090 Temuco, Chile. ${ }^{3}$ Universidad Austral de Chile, Facultad de Ciencias Forestales y Recursos Naturales, Escuela de Graduados, Valdivia, Chile Campus Isla Teja, Los Laureles 095, Recinto Isla Teja, Valdivia, Chile. ${ }^{4}$ Centro de Investigación Dinámica de Ecosistemas Marinos de Altas Latitudes (IDEAL) Campus Isla Teja, Calle Los Laureles 095, Recinto Isla Teja, Valdivia, Chile. ${ }^{5}$ Núcleo de Estudios Ambientales (NEA), Universidad Católica de Temuco, Avenida Rudecindo Ortega No 02950 Campus San Juan Pablo II, Temuco, Chile. ${ }^{6}$ Departamento de Ciencias Ambientales, Facultad de Recursos Naturales, Universidad Católica de Temuco, Avenida Rudecindo Ortega Nº2950

Campus San Juan Pablo II, Temuco, Chile.

Received: 11 October 2018 Accepted: 9 April 2019

Published online: 29 April 2019

\section{References}

Basco-Carrera L, Warren A, van Beek E, Jonoski A, Giardino A (2017) Collaborative modelling or participatory modelling? A framework for water resources management. Environ Model Softw 91:95-110

Bateman IJ, Harwood AR, Mace GM, Watson RT, Abson DJ, Andrews B, Binner A, Crowe A, Day BH, Dugdale S, Fezzi C, Foden J, Hadley D, Haines-Young R, Hulme M, Kontoleon A, Lovett AA, Munday P, Pascual U, Paterson J, Perino G, Sen A, Siriwardena G, van Soest D, Termansen M (2013) Bringing ecosystem services into economic decision-making: land use in the United Kingdom. Science 341(6141):45-50

Boyd J, Banzhaf S (2007) What are ecosystem services? The need for standardized environmental accounting units. Ecol Econ 63(2-3):616-626

Braat LC, de Groot R (2012) The ecosystem services agenda: bridging the worlds of natural science and economics, conservation and development, and public and private policy. Ecosyst Serv 1(1):4-15

CIREN (2002) Descripciones de suelos, materiales y símbolos: Estudio agrológico IX Región. Publicación CIREN N 122. Centro de Información de Recursos Naturales (CIREN), Santiago

Clarke KR, Tweedley JR, Valesini FJ (2014) Simple shade plots aid better long-term choices of data pre-treatment in multivariate assemblage studies. J Mar Biol Assoc UK 94(1):1-16

CONAF (2013) Proyecto Catastro y Evaluación de los Recursos Vegetacionales Nativos de Chile. Corporación Nacional Forestal, Santiago http://sit.conaf.cl/. Accessed 14 Aug 2018

Costanza R, D'arge R, De Groot R, Farber S, Grasso M, Hannon B, Limburg K, Naeem S, O'Neill RV, Paruelo J, Raskin RG, Sutton P, vans den Belt M (1997) The value of the world's ecosystem services and natural capital. Nature 387: 253-260. https://doi.org/10.1038/387253a0

Costanza R, Shuang L (2014) Ecosystem services and environmental governance: comparing China and the U.S. Asia Pac Policy Stud 1(1):160-170. https://doi. org/10.1002/app5.16

Daily G (1997) Nature's services: societal dependence on natural ecosystems. Island Press, Washington D.C

Dassou AG, Tixier P, Dépigny S, Carval D (2017) Vegetation structure of plantainbased agrosystems determines numerical dominance in community of ground-dwelling ants. PeerJ 5:e3917. https://doi.org/10.7717/peerj.3917

de Groot R, Wilson M, Boumans R (2002) A typology for the classification, description and valuation of ecosystem functions, goods and services. Ecol Econ 41(3):393-408

De los Ríos Escalante P, Soto D, Santander-Massa R, Acevedo P (2017) Plankton crustaceans in bays with different trophic status in Llanquihue lake $\left(41^{\circ} \mathrm{S}\right.$ (hile). Braz J Biol 77:469-475

Delgado-Aguilar M, Konold W, Schmitt C (2017) Community mapping of ecosystem services in tropical rainforest of Ecuador. Ecol Indic 73:460-471

Di Castri F, Hajek E (1976) Bioclimatología de Chile. Ediciones Universidad Católica de Chile, Santiago

Díaz S (2006) Biodiversity regulation of ecosystem services. In: Hassan R, Scholes $\mathrm{R}$, Ash N (eds) Ecosystems and human well-being: Current state and trends, 
Vol 1. Findings of the condition and trends working Group of the Millennium Ecosystem Assessment. Island Press, Washington D.C

Diaz-Balteiro L, Belavenutti P, Ezquerro M, González-Pachón J, Ribeiro Nobre S, Romero C (2018) Measuring the sustainability of a natural system by using multicriteria distance function methods: some critical issues. J Environ Manag 214:197-203

Donoso P, Otero L (2005) Hacia una definición de País Forestal: ¿Dónde se sitúa Chile? Bosque 26(3):5-18

Echeverría C, Coomes D, Salas J, Rey J, Lara A, Newton A (2006) Rapid deforestation and fragmentation of Chilean temperate forests. Biol Conserv 130:481-494

Esse C, Valdivia P, Encina-Montoya F, Aguayo C, Guerrero M, Figueroa D (2014) Modelo de análisis espacial multicriterio (MAEM) para el mapeo de servicios ecosistémicos en cuencas forestales del sur de Chile. Bosque 35(3):289-299

Fisher B, Turner RK (2008) Ecosystem services: classification for valuation. Biol Conserv 141:1167-1169

Gómez-Orea D (1999) Evaluación de impacto ambiental: un instrumento preventivo para la gestión ambiental. Ediciones Mundi-Prensa, Madrid

Gómez-Orea D, Gómez MT (2014) Marco conceptual para la ordenación territorial y reflexiones sobre el proceso ecuatoriano en la materia: una visión sobre qué es, para qué sirve, como se hace y como se viene haciendo la ordenación territorial en Ecuador. Documento presentado en el IX simposio nacional de desarrollo urbano y planificación territorial, Universidad de Cuenca, Ecuador, 28-30 de Octubre de 2014.

Habib TJ, Heckbert S, Wilson JJ, Vandenbroeck A, Cranston J, Farr D (2016) Impacts of land-use management on ecosystem services and biodiversity: an agent-based modelling approach. PeerJ 4:e2814. https://doi.org/10.7717/ peerj.2814

Haines-Yong R, Potschin M (2013) CICES V4.3 - revised report prepared following consultation on CICES version 4, august-December 2012. EEA framework contract no EEA/IEA/09/003. https://unstats.un.org/unsd/envaccounting/ seearev/GCComments/CICES_Report.pdf. Accessed 15 Aug 2018

Haines-Young R, Potschin M (2018) Common international classification of ecosystem services (CICES) V5. 1 and guidance on the application of the revised structure. EEA. www.cices.eu. Accessed 17 Aug 2018

Hermelingmeier V Nicholas K (2017) Identifying five different perspectives on the ecosystem services concept using Q methodology. Ecol Econ 136:255-265

Kassambara A, Mundt F (2017) Factoextra: extract and visualize the results of multivariate data analyses. R package version 1.0.5. https://CRAN.R-project. org/package=factoextra. Accessed 13 July 2018

Keller A, Fournier E, Fox J (2015) Minimizing impacts of land use change on ecosystem services using multi-criteria heuristic analysis. J Environ Manag 156:23-30

Lara A, Little C, Urrutia R, McPhee J, Álvarez-Garretón C, Oyarzún C, Soto D, Donoso P, Nahuelhual L, Pino M, Arismendi I (2009) Assessment of ecosystem services as an opportunity for the conservation and management of native forests in Chile. Forest Ecol Manag 258(4):415-424

Lara A, Soto D, Armesto J, Donoso P, Wernli C (2003) Componentes científicos clave para una política nacional sobre usos, servicios y conservación de los bosques nativos chilenos. Universidad Austral de Chile, Valdivia

Larsen R, Swartling Ä, Powell N, May B, Plummer R, Simonsson L, Osbeck M (2012) A framework for facilitating dialogue between policy planners and local climate change adaptation professionals: cases from Sweden, Canada and Indonesia. Environ Sci Pol 23:12-23

Laterra P, Castellarini F, Orúe ME (2011) ECOSER: Un protocolo para la evaluación biofísica de servicios ecosistémicos y la integración con su valor social. In: Laterra P, Jobbágy E, Paruelo J (eds) Valoración de Servicios Ecosistémicos, Conceptos, herramientas y aplicaciones para el ordenamiento territorial. Ediciones INTA, Buenos Aires

Little C, Lara A, McPhee J, Urrutia R (2009) Revealing the impact of forest exotic plantations on water yield in large scale watersheds in south-Central Chile. J Hydrol 374(1-2):162-170

Luebert F, Pliscoff P (2006) Sinopsis bioclimática y vegetacional de Chile. Editorial Universitaria, Santiago de Chile

MEA (2005) Millennium ecosystem assessment synthesis report. Island Press, Washington

Miranda A, Altamirano A, Cayuela L, Pincheira F, Lara A (2015) Different times, same story: native forest loss and landscape homogenization in three physiographical areas of south-Central Chile. Appl Geogr 60:20-28

Naiman R, Decamps H, McClain ME (2005) Riparia: ecology, conservation, and management of streamside communities. Elsevier Academic Press, London
Odum E (2004) Fundamental of Ecology, 5th edition. Editorial Thomson Brooks/ Cole, Belmont

Otero L (2006) La huella del fuego. Historia de los bosques nativos. Poblamiento y cambios en el paisaje del sur de Chile, Santiago, p 171

Oyarzún C, Campos H, Huber A (1997) Exportación de nutrientes en microcuencas con distinto uso del suelo en el sur de Chile (Lago Rupanco, decima Región). Rev Chil Hist Nat 70:507-519

Oyarzún C, Nahuelhual L, Núñez D (2005) Los servicios ecosistémicos del bosque templado Iluvioso: producción de agua y su valoración económica. Rev Ambiente y Desarrollo 20(3):88-95 21(1)

Peterson GD, Harmackova ZV, Meacham M, Queiroz C, Jiménez-Aceituno A, Kuiper JJ, Malmborg K, Sitas NE, Bennett E (2018) Welcoming different perspectives in IPBES: "Nature's contributions to people" and "ecosystem services". Ecol Soc 23(1):39. https://doi.org/10.5751/ES-10134-230139

Quinn G, Keough M (2002) Experimental design and data analysis for biologists. Cambridge University Press, Cambridge

Rees P (2018) Ecosystems, energy and nutrients. In: Rees P (ed) Examining ecology. Academic Press, pp 51-79. https://doi.org/10.1016/B978-0-12809354-2.00003-8

Richardson D, Holmes PM, Esler K, Galatowitsch S, Stromberg J, Kirkman S, Pysek P, Hobbs R (2007) Riparian vegetation: degradation, alien plant invasions and restoration prospects. Divers Distrib 13:126-139

Rodríguez F (2006) Cuencas hidrográficas, descentralización y desarrollo regional participativo. Inter Sedes 7:113-125

Sánchez JLS (2009) Redes alimentarias alternativas: concepto, tipología y adecuación a la realidad española. B Asoc Geógr Esp 49:185-207

Santander-Massa R (2014) Profesionales del área ambiental y el uso de un sistema de información geográfica aplicado en sistemas rurales Mapuches del centro-sur de Chile. Ambiente y Desarrollo 18(34):13-26 https://revistas. javeriana.edu.co/index.php/ambienteydesarrollo/article/view/9737. Accessed 18 Aug 2018

Soto D (2002) Oligotrophic patterns in southern Chile lakes: the relevance of nutrients and mixing depth. Rev Chil Hist Nat 75:377-393

TEEB (2010) The economics of ecosystems and biodiversity ecological and economic foundations. In: Kumar P (ed) Earthscan, London and Washington

Uhde B, Andreas Hahn W, Griess VC, Knoke T (2015) Hybrid MCDA methods to integrate multiple ecosystem Services in Forest Management Planning: a critical review. Environ Manag 56:373-388. https://doi.org/10.1007/s00267015-0503-3

Verburg R, Selnes T, Verweij P (2016) Governing ecosystem services: national and local lessons from policy appraisal and implementation. Ecosyst Serv 18:186-197

Vuscoviuch JL, Tavares Y (2011) Implementación de prácticas públicas y privadas relacionadas al ordenamiento territorial a través de la determinación de unidades de paisaje en la cuenca hidrográfica del lago vichuquén, Chile. Rev Geográfica de Am Cen 2:1-22

Wallace KJ (2007) Classification of ecosystem services: problems and solutions. Biol Conserv 139(3-4):235-246

Wickham H (2009) ggplot2: elegant graphics for data analysis. Springer-Verlag, New York

Zasada I, Häfner K, Schaller L, van Zanten B, Lefebvre M, Malak-Rawlikowska A, Nikolov D, Rodríguez-Entrena M, Manrique R, Ungaro F, Zavalloni M, Delattre L, Piorr A, Kantelhardt J, Verburg P, Viaggi D (2017) A conceptual model to integrate the regional context in landscape policy, management and contribution to rural development: literature review and european case study evidence. Geoforum 82:1-12 